\title{
The Importance of using Arbutus Pavarii Plant as a Medicinal Herbal Plant and its Benefits in our Daily Life
}

\author{
Halima Omar Jadallah ${ }^{1 *}$, Hossam B. Bahnasy ${ }^{4}$, Mohamed Younes A. Hassan ${ }^{2}$, Sabah Lamlom ${ }^{1}$, \\ Idress Hamad Attitalla ${ }^{3}$

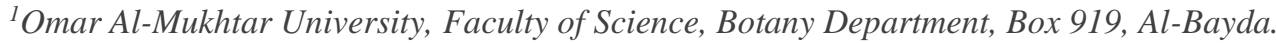 \\ ${ }^{2}$ Azhar University and chemist at Minya Company for drinking water and Sanitation, Elminia, Egypt. \\ ${ }^{3}$ Omar Al-Mukhtar University, Faculty of Science, Department of Microbiology, Box 919, Al-Bayda. \\ ${ }^{4}$ Omar Al-Mukhtar University, faculty of Medical Technology, Department of Lab Medicine and Medical \\ Microbiology, Box 919, Al-Bayda, Libya
}

*Corresponding Author: Halima Omar Jadallah, Omar Al-Mukhtar University, Faculty of Science, Botany Department, Box 919, Al-Bayda.

\begin{abstract}
Arbutus pavarii Pamp. (Ericaceae) is one of the endemic species in Libya. Samples of the non-ripened and ripened fruits of Arbutus pavarii Pamp. Were collected from its natural habitat (El-Gabel El-Akhdar, Libya). Fruit characters as fruit size, weight, fruit mass and seeds per fruit were estimated. The vitamin content of $A, C$ and $E$ was estimated using different methods. The total phenolic and flavonoids content of the fruits was determined spectrophotometrically. The antioxidant activity was assessed using a modified quantitative (DPPH) assay at two maturation stages of fruits (green and red). The results were discussed according to the nutritional value of the fruits. The human impacts and their effects on plant vegetation and biodiversity became a field of major interest in the last few years. many of human activities occurred in AL-jabal AL-akhdar area as result of increase of development activities and growth of population. The present investigation was carried out to study the Important of Arbutus pavarii Pamp. (Ericaceae) as A herbaceous plant useful in medicinal uses, as well as many benefits in use and national economic wealth. The paper presents the results of phytochemical screening, antioxidant, antimicrobial and anti-prolife rative activity studies of Arbutus pavarii (A. pavarii) plant. The whole aerial part of the plant was collected during the spring season (2020), identified and extracted with methanol, chloroform and n-Hexane. Phytochemical screening was carried out using standard procedures. Antioxidant activity was done using 2, 2, Diphenyl-1-picryhydrazyl (DPPH) assay. Antimicrobial evaluation was performed using agar well diffusion method. The anti-proliferative activity was evaluated on two breast adenocarcinoma and lung car cinoma cells. Phytochemical screening showed the presence of flavonoids, tannins, glycosides, simple phenolic, free reducing sugers, triterpenes and sterols in the plant extract.
\end{abstract}

Keywords: Arbutus Pavarii, Antioxidant Activity, Antimicrobial Activity, Anti-Proliferative Activity.

\section{INTRODUCTION}

Arbutus pavarii Pamp. (Ericaceae) is one of the endemic species in Libya and it distributes naturally as wild plant in El-Gabel El-Akhdar area, which characterized with Mediterranean climatic conditions (Elshatshat 2009; Elshatshat et al 2009; and Elabidi and Elshatshat 2017). It is evergreen shrub or small tree, 1.5 to $3 \mathrm{~m}$ tall with reddish brown peeling bark. The flowering season appear from late October to February and the flowers are a good source of nectar for bees. Because of its nutritional and medicinal value, A. pavarii Pamp. honey is widely used for folk medicinal purposes (El abidi and Elshatshat 2017), in addition, other honey types which collected from other plant species (Elshatshat and Elsilini 2017). The fruit takes around 8 months to ripen, and they are spherical and warty, and turn from yellow to orange to scarlet as the autumn progresses (figure 1). The strawberry fruits are edible directly as fruits or can be made into jam, but the taste is somewhat insipid (Elshatshat 2009). Increasing phenolic compounds in some native plants is one of the strategies of these species to avoid drought stress in arid and semi-arid zones like Libya. According to many studies, the phenolic compounds of the leaves and fruits of Arbutus genus, especially Arbutus unedo L. were reported, identified and investigated (Ayaz, et al. 2000; Fortalezas, et al. 2010; Guimarães, et al. 2013; Hamad, et al. 2011; and Pawlowska, et al. 2006). In addition, the antioxidant properties and activities (Isbilir, et al. 2012; Mendes, et al. 2011). Because of its endemism and lack of information about the fruits of Arbutus pavarii Pamp., this work was conducted to shade some light on the fruit characters and the characterization 
of the antioxidant composition at different fruit ripening stages. Plant biodiversity is reported that one of important genetic resources of many species growing spontaneously around the Mediterranean basin ( Louhaichi et al, 2011). Libya is one of Mediterranean basin country and a native of many plant species that model of biodiversity (El- Darier and El-Mogaspi, 2009). Plants that have economic importance such as Haplophyllum tuberculatum (Forsk) and Strawberry trees (Arbutus pavarii) which are located in different environments (coastal, mountainous and desert) in Libya (El-Darier and El-Mogaspi, 2009). There are a number of factors for the difficulty of germination and growth of these plants naturally in the wild land. Drop in rate of rainfall annually it is the most important environmental factor which has made the wild lands drier and decreased significantly seeds germination (Elmaghrabi at al. 2017). In addition, overgrazing and the use of lumber as firewood and also expansion of new farms, which contributed of deterioration sharply of edible and medical wild plant resources which led these species to endanger (Elmaghrabi et al 2017). The genus Arbutus belongs to the Vaccinioideae subfamily which includes evergreen shrub-like woody taxa with laurel-like and sclerophyllous leaves of the Ericaceae family (Torres et al., 2002). There were about six species of Arbutus grows spontaneously around the Mediterranean basin. The species is drought tolerant and able to regenerate following forestry fires making it quite interesting for forestation programs in Mediterranean regions. Fruits are used to make jellies and a spirit which represents the main income for owners (Torres et al., 2002). Arbutus pavarii species it is only located in the coast of Libya especially at ElJabal El-Akhdar Region in the Mediterranean regions (El-Darier and El-Mogaspi, 2009). Haplophyllum tuberculatum (Forsk) juss that belongs to the Rutaceae familly (El-Naggar et al., 2014). Haplophyllum tuberculatum is a herbal plant is, simple leaves, reciprocal, heterogeneous white, small yellow flowers (Puricelli et al., 2002). The whole plant is being used in pharmaceutical product with the exception of the roots. The essential oil of Haplophyllum tuberculatum was reported by (Al-Rehaily et al, 2014) which prepared by hydrodistillation of the fresh flowering aerial parts of the plant collected from wild types. The oil was subsequently analyzed by GC and GC-MS. Thirty-seven compounds, accounting for $96.4 \%$ of the oil composition were identified in this study (Al-Rehaily et al, 2014). The antimicrobial and activity of the essential oil was also evaluated against various human pathogens, where a relatively low inhibitory range was observed. Because these species (Haplophyllum tuberculatum and Arbutus pavarii) which have good economic value and, the scarcity of plant biomass available in the natural habitat, we set up non-conventional methods for plant propagation from nodal stem segments and, at the same time, we established cell cultures of the plant (Elmaghrabi et al, 2017).

\section{MATERIALS AND METHODS}

\subsection{Materials}

\subsubsection{Plant Material}

The samples of Arbutus Pavarii. Collected from the EL-Gabal EL-Akhdar area (Asulntah area) and then choose three random plants were next to some includes (Sample1= plant intact naturally grow, sample $2=$ plant grow almost normal and sample $3=$ No plant grows naturally). All samples were collected from the same location.

\subsubsection{Chemicals}

1, 1-Diphenylpicrylhydrazyl ( $\left.\mathrm{DPPH}^{\circ}\right)$, methanol, Ethanol and acetone were supplied by Sigma and Merck company. Ascorbic acid, Folin-Ciocalteu reagent, ferric chloride, potassium ferricyanide, monobasic dihydrogen phosphate, dibasic monohydrogen phosphate, trichloro acetic acid, sodium carbonate, anhydrous sodium sulfate and pyrogallol were obtained from the biochemistry laboratory of Chemistry department-Benghazi University.

\section{METHODS}

\subsection{Extraction of Essential Oil from Leaves of Arbutus Pavarii. (Sample 1, Sample 2 and Sample 3)}

The dry powdered leaves of Juniperus phoenicea (500g) were subjected to hydro distillation using Clevenger apparatus. The isolation of volatile oils was completed within 6 hours (Clevenger, 1928).

\subsubsection{Store Essential Oils}

The oil samples were stored at $7^{\circ} \mathrm{C}$ in dark air-tight containers after drying over anhydrous sodium sulfate and filtered before injecting to GC-MS analysis. 


\subsection{Oil Analysis}

The oil samples extracted from leaves of Arbutus Pavarii. Were subjected to the following tests:

\subsubsection{Gas Chromatography/Mass Spectra}

Thermo Scientific, Trace GC Ultra \& ISQ Single Quadruple MS, DB-5 bonded-phase fused-silica capillary column was used in for GC/MS analysis of essential oils. This experiment has been conducted in the central laboratory at Cairo University-Egypt.

\subsubsection{Antioxidant Activities Assays and Quantitative Analysis}

All these experimental assays have been conducted in biochemistry laboratory at Benghazi University.

\section{Total Phenolic Content (TPC):}

Total concentration of phenolic compound in all oil extracts obtained from leaves of Arbutus Pavarii. Was estimated using the colorimetric method based on Folin-Ciocalteu reagent (Sawsan et al. 2010). $0.05 \mathrm{ml}$ of the oils at different concentrations "100,200,300,400,500 $\mu \mathrm{g} / \mathrm{ml}$ " were mixed separately with $0.05 \mathrm{ml}$ of Folin-Ciocalteu reagent. Then $0.5 \mathrm{ml}$ of $15 \%$ sodium carbonate solution was added to the mixture and then the adjusted to $1 \mathrm{ml}$ with $0.4 \mathrm{ml}$ of distilled water. The reaction was allowed to stand for $10 \mathrm{~min}$, after which the absorbance was recorded at $725 \mathrm{~nm}$ by UV-visible spectrophotometer. Quantification was done with respect to standard calibration curve of Pyrogallol the results were expressed as pyrogallol " $\mu \mathrm{g} / \mathrm{ml}$ " Fig (6). Estimation of the phenolic compounds was carried out in triplicates. The results were mean values (standard deviations).

Table1. Total phenolic content (TPC) of Pyrogallol

\begin{tabular}{|c|c|}
\hline $\begin{array}{c}\text { Concentration of Pyrogallol } \\
\text { " } \boldsymbol{\mu g} / \mathbf{m l} "\end{array}$ & $\begin{array}{c}\text { Mean } \\
\text { ( Standard Deviation) }\end{array}$ \\
\hline 100 & $0.410(0.032)$ \\
\hline 200 & $0.799(0.0220)$ \\
\hline 300 & $1.333(0.0045)$ \\
\hline 400 & $1.828(0.0117)$ \\
\hline 500 & $2.105(0.0225)$ \\
\hline
\end{tabular}

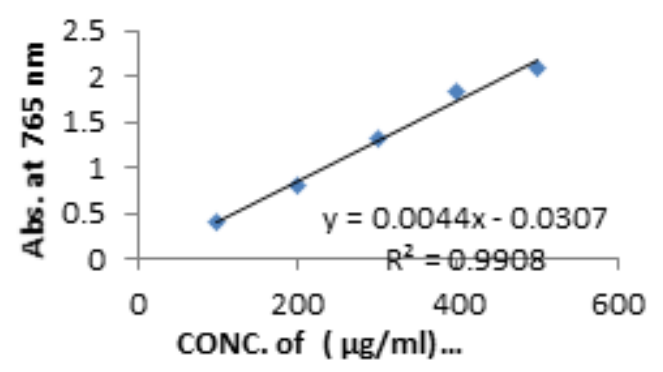

\section{Total Flavonoids Content (TFC)}

Aluminum chloride colorimetric method was used for determination of total flavonoids (Chang $\boldsymbol{e t}$ al., 2002). $2 \mathrm{ml}$ of different concentration "100, 200,300, $400,500 \mu \mathrm{g} / \mathrm{ml}$ " of oil extracts mixed with $0.1 \mathrm{ml}$ of $10 \%$ aluminum chloride, $0.1 \mathrm{ml}$ of $1 \mathrm{M}$ potassium acetate and $2.8 \mathrm{ml}$ of distilled water. It kept at room temperature for $30 \mathrm{~min}$; the absorbance of the reaction mixture was measured at $415 \mathrm{~nm}$ with a UV-visible spectrophotometer. The calibration curve was obtained by preparing different quercetin solutions in methanol at concentrations "100 to $500 \mu \mathrm{g} / \mathrm{ml}$ " Fig (7).

Table2. Total flavonoids content of quercetin

\begin{tabular}{|c|c|}
\hline $\begin{array}{c}\text { Concentration of qurecetin } \\
\text { " } \boldsymbol{\mu g} / \mathbf{m l} \text { " }\end{array}$ & $\begin{array}{c}\text { Mean } \\
\text { ( Standard Deviation) }\end{array}$ \\
\hline 100 & $0.279(0.092)$ \\
\hline 200 & $0.560(0.035)$ \\
\hline 300 & $0.834(0.003)$ \\
\hline 400 & $1.066(0.009)$ \\
\hline 500 & $1.300(0.006)$ \\
\hline
\end{tabular}




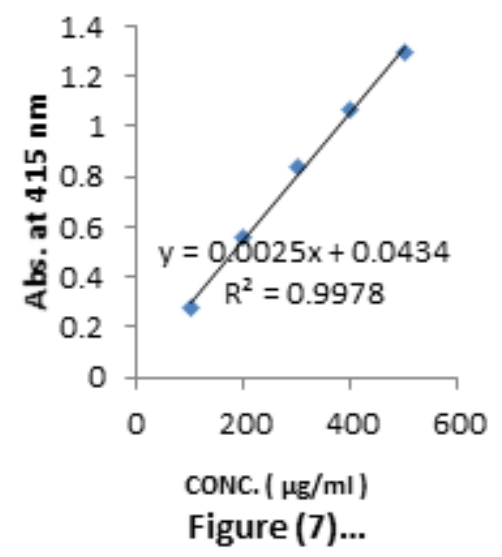

\section{Reducing Power Assay (RPA)}

The reducing power was determined according to (Naznin and Hasan, 2009). $2 \mathrm{ml}$ of the all oil extracts with different concentrations "100,200,300,400,500 $\mathrm{\mu g} / \mathrm{ml}$ " were mixed with $2.5 \mathrm{ml}$ phosphate buffer $(0.2 \mathrm{M}, \mathrm{pH} 6.6)$ and $2.5 \mathrm{ml}$ potassium ferricyanide then mixture was incubated in water bath at $50 \mathrm{C}^{0}$ for 20 minutes and $2.5 \mathrm{ml}$ of trichloroacetic acid was added to the mixture which was then centrifuged at $3000 \mathrm{rpm}$ for 10 minutes. Finally, $2.5 \mathrm{ml}$ of the supernatant was mixed with $2.5 \mathrm{ml}$ of distilled water and $1 \mathrm{ml} \mathrm{Fecl}$, substances, which have reduction potential react with potassium ferricyanide $\left(\mathrm{Fe}^{3+}\right)$ to form potassium ferricyanide $\left(\mathrm{Fe}^{2+}\right)$, which then reacts with ferric chloride to form ferric ferrous complex that has an absorption maximum at 700nm by UV-Visible spectrophotometer. Quantification was done with respect to standard calibration curve of ascorbic acid the results were expressed as ascorbic acid " $\mu \mathrm{g} / \mathrm{ml} "$ Fig (8).

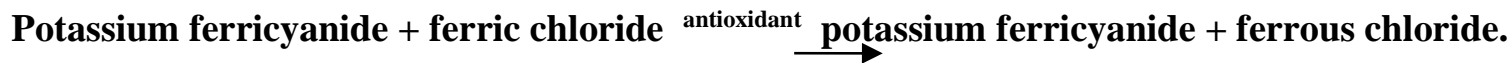

Table3. Reducing power assay of vitamin C

\begin{tabular}{|c|c|}
\hline $\begin{array}{c}\text { Concentration of vitamin C } \\
\text { " } \boldsymbol{\mu g} / \mathbf{m l} "\end{array}$ & $\begin{array}{c}\text { Mean (Standard } \\
\text { Deviation) }\end{array}$ \\
\hline 100 & $0.201(0.0280)$ \\
\hline 200 & $0.495(0.0350)$ \\
\hline 300 & $0.697(0.0087)$ \\
\hline 400 & $0.992(0.0727)$ \\
\hline 500 & $1.201(0.0305)$ \\
\hline
\end{tabular}

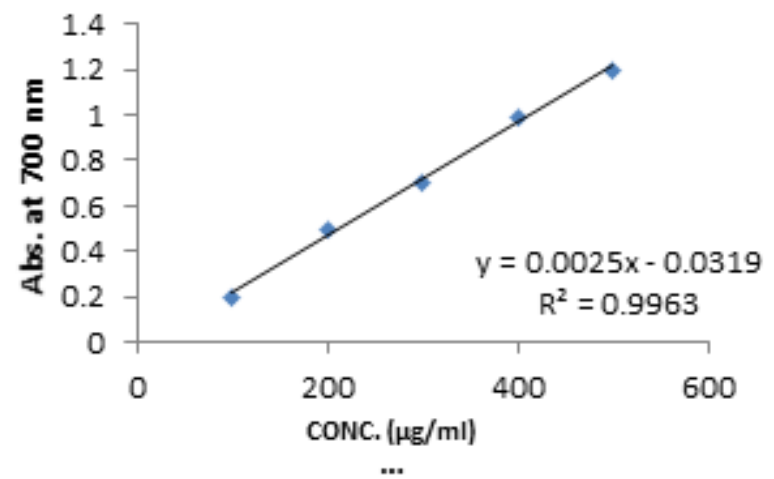

\section{DPPH Free Radical Scavenging Activity (RSA)}

The antioxidant activity of all oil extracts were measured in terms of hydrogen donating or radicalscavenging ability using the stable DPPH 'method as modified by (Potapovich and Kostyuk 2003). The reaction mixture containing $2 \mathrm{ml}$ of all extracts at different concentrations "100,200,300,400,500 $\mu \mathrm{g} / \mathrm{ml}^{\prime}$ and $2 \mathrm{ml}^{\text {of }} \mathrm{DPPH}^{*}(0.2 \mathrm{mM})$ was vigorously shaken and incubated in darkness at room temperature for 30 minutes. When the $\mathrm{DPPH}^{\circ}$ reacted with an antioxidant compound in oil that can donate hydrogen, it was reduced and resulting in decrease of absorbance at $517 \mathrm{~nm}$ using UV-visible spectrophotometer, and the mean values were obtained from triplicate experiments. The 
percentage of the remaining $\mathrm{DPPH}^{*}$ was plotted against the sample concentration. A lower value indicates greater antioxidant activity. Radical scavenging activity was expressed as percent ages of inhibition and was calculated using the following formula: -

\section{\%DPPH "RSA" = [Abs. of Control - Abs. of Sample / Abs. of Control $]$ x 100}

\subsection{Growth Characteristics of J. Phoenicea}

The study samples were divided into lots different tree, depending on the appearance exterior of the tree with three replicates in each tree were made to find out the quantitative and morphological differences.

\subsection{Estimation of Photosynthetic Pigments}

The photosynthetic pigments were extracted from a known fresh weight of leaves in $85 \%$ aqueous acetone to a certain concentration for spectrophotometric measurements. The photosynthetic pigments (chlorophyll a, b and carotenoids) were determined by spectrophotometric method as described by Metzner et al. (1965). The pigments extract was measured against a blank of pure $85 \%$ aqueous acetone at three wavelengths of 452.5, 644 and $663 \mathrm{~nm}$. Taking into consideration the dilution factor, it was possible to determine the concentration of pigment fractions (chl. a, b and carotenoides) as $\mathrm{mg} / \mathrm{ml} \mathrm{using}$ following equations:

Chlorophyll $\mathrm{a}=10.3 \mathrm{E}_{663}-0.918 \mathrm{E}_{644}=\mathrm{mg} / \mathrm{ml}$

Chlorophyll $b=19.7 \mathrm{E}_{644}-3.87 \mathrm{E}_{663}=\mathrm{mg} / \mathrm{ml}$

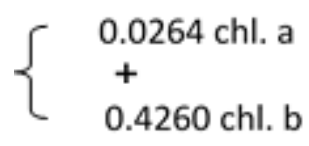

Charotenoids $=4.2 \mathrm{E}_{452.5}=\mathrm{mg} / \mathrm{ml}$

Finally, these pigment fractions were calculated as $\mathrm{mg} / \mathrm{g}$ fresh matter

\subsection{The Estimation of Microbial Number}

\subsubsection{Nutrient Agar medium}

$23 \mathrm{~g}$ of nutrient agar medium were suspened in 1-liter $\mathrm{ml}$ distilled water and then heat to boiling to dissolve the medium completely. Sterilized by autoclaving at $15 \mathrm{lbs}$ pressure (121 C) for $15 \mathrm{~min}$.

\subsubsection{Pure Culture}

A single bacterial colony from each mixed culture was taken by loop, streaked on nutrient agar medium, and incubated at $37.5^{\circ} \mathrm{C}$ for three days.

\subsubsection{Gram Stain}

Differential stains (Gram stain) was carried out to confirm that the bacteria were gram negative and rode shaped. Smears from single colony bacteria grown on EMB at $37{ }^{\circ} \mathrm{C}$ and $44.5^{\circ} \mathrm{C}$ were prepared and covered by primary stain (Crystal violet) for $1 \mathrm{~min}$ and then Mordant (Iodine) for $1 \mathrm{~min}$ to made CV-I complex after that decolorized agent (70\% ethanol) was washed the slide to remove the CV-I complex in the thin layer of peptidoglycan of gram negative bacteria. Wall. Drops of counter stain (safranin) were added for a half minute.was The slide then washed in The distilled water and dried by filter paper after that examined by microscope using an oil immeration lens. In summary, gram-positive cells retain the dye and remain purple, Gram-negative cells did not retain the dye; they were colorless until counterstained with a red dye (pink cells).

\subsubsection{Endospore Staining}

A film was made on a clean slide by emulsifying part of a colony in loopful of distilled water. The film was then air-dried and stained with malachite green for 4-5 min, using a flame. The smear was rinsed rapidly with water and stained with safranin solution for $30 \mathrm{sec}$. The slide was washed with water and allowed to dry. On microscopic examination the endospores appeared green and the cells were pink (Abualdahab and Gorani, 1983). 


\section{RESULTS}

\subsection{Antioxidant Evaluation of Essential Oils Extracted from Leaves of Arbutus Pavarii Pamp. (Ericaceae).}

The antioxidant activities of essential oils extracted of three samples from leaves of Arbutus pavarii Pamp. (Ericaceae) growing in Al-Jabal Al Akhdar were evaluated by:

\subsubsection{Total Phenolic Content (TPC):}

Figure (9) show the total phenolic content found in essential oils where the essential oil of sample number (1) contained high total phenolic content, the results expressed according to pyrogallol as phenolic compound in figure (6).

\subsubsection{Total Flavonoids Content (TFC):}

The results obtained in this study as shown in figure (10) indicated that the essential oil of healthy sample contain high amounts of flavonoids compounds as compared with the qurecetin in figure (7) which was used as standard.

\subsubsection{Reducing Power Assay (RPA):}

As shown in figure (11) the reducing power assay of essential oil of sample 1and sample 2 exhibit higher reducing activity than the ascorbic acid.

\subsubsection{The DPPH'Radical Scavenging Activity:}

The result of the $\mathrm{DPPH}^{*}$ radical scavenging activity of essential oil are shown in figure (12), this result compared with the well-known antioxidant ascorbic acid were the percent of the inhibition is $97 \%$ at $500 \mu \mathrm{g} / \mathrm{ml}$ of the essential oil of sample 1 and $92 \%$ at $500 \mu \mathrm{g} / \mathrm{ml}$ of the essential oil of sample 2, while the percent of the inhibition is $38 \%$ at $500 \mu \mathrm{g} / \mathrm{ml}$ of the essential oil sample 3 .

Table4. Total phenolic content (TPC) of essential oils extracted of three samples from leaves Arbutus pavarii (Sample1= plant intact naturally grow, sample $2=$ plant growth almost normal, sample $3=$ No plant grows naturally) and \% variation from the corresponding control (pyrogallol as standard)

\begin{tabular}{|c|c|c|c|c|c|c|c|}
\hline \multirow{2}{*}{$\begin{array}{c}\text { concentration } \\
" \mu \mathrm{g} / \mathrm{ml} "\end{array}$} & \multicolumn{7}{|c|}{ Mean phenolic content (Standard Deviation) } \\
\hline & Pyrogallol & Sample1 & \% var. & Sample2 & \% var. & Sample3 & $\%$ var. \\
\hline $100(1)$ & $\begin{array}{l}0.410( \\
0.032)\end{array}$ & $0.711(0.03)^{*}$ & $73.4 \uparrow$ & $\begin{array}{c}0.699)^{*} \\
0.05)^{*}\end{array}$ & $70.5 \uparrow$ & $\begin{array}{c}0.025 \\
0.0162)^{* * *}\end{array}$ & $97.5 \downarrow$ \\
\hline 200 & $\begin{array}{c}0.799 \\
(0.0220) \\
\end{array}$ & $\begin{array}{c}0.799(0 . \\
01) \dagger\end{array}$ & Zero & $\begin{array}{c}0.782 \\
(0.011) \dagger\end{array}$ & $2.13 \downarrow$ & $\begin{array}{c}0.085 \\
0.020)^{* *}\end{array}$ & $89.4 \downarrow$ \\
\hline 300 & $\begin{array}{c}1.333( \\
0.0045)\end{array}$ & $\begin{array}{l}1.435( \\
0.02) \dagger\end{array}$ & $7.65 \uparrow$ & $\begin{array}{l}0.988)^{*} \\
0.002)^{*}\end{array}$ & $31.2 \downarrow$ & $\begin{array}{c}0.222)^{* *} \\
0.022)^{* *}\end{array}$ & $84.5 \downarrow$ \\
\hline 400 & $\begin{array}{c}1.828( \\
0.0117) \\
\end{array}$ & $1.78(0.01) \dagger$ & $2.63 \downarrow$ & $\begin{array}{c}1.56( \\
0.016) \dagger\end{array}$ & $12.4 \downarrow$ & $0.754(0.036)^{*}$ & $57.6 \downarrow$ \\
\hline 500 & $\begin{array}{l}2.105( \\
0.0225)\end{array}$ & $\begin{array}{c}2.69( \\
0.07) \dagger\end{array}$ & $27.8 \uparrow$ & $\begin{array}{c}2.21( \\
0.009) \dagger\end{array}$ & $17.8 \downarrow$ & $\begin{array}{c}1.061 \\
(0.037)^{* *}\end{array}$ & $60.6 \downarrow$ \\
\hline
\end{tabular}

$\dagger$ Insignificant difference from the corresponding control at $\mathrm{P}>0.1$

* Significant difference from the corresponding control at $\mathrm{P}<0.05$

** Highly sig. difference from the corresponding control at $\mathrm{P}<0.01$

*** Very highly sig. difference from the corresponding control at $\mathrm{P}<0.001$

$\downarrow$ Decrease

$\uparrow$ Increase

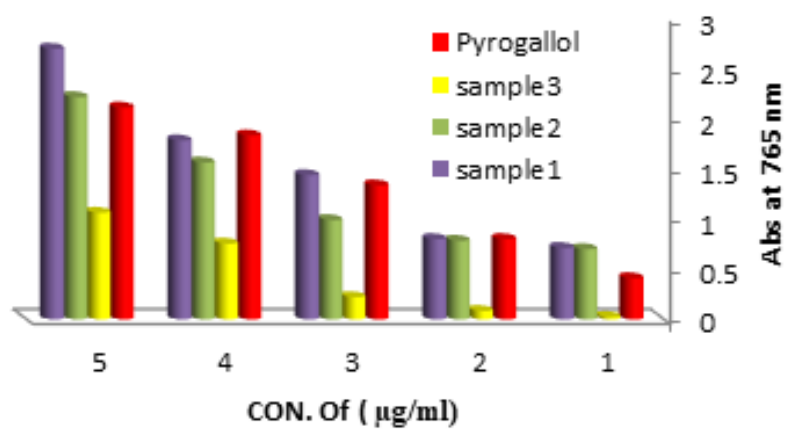

Fig9. Total phenolic content (TPC) of essential oils extracted from leaves Arbutus pavarii and Pyrogallol as phenolic compound. 
The Importance of using Arbutus Pavarii Plant as a Medicinal Herbal Plant and its Benefits in our Daily Life

Table5. Total flavonoids content essential oils extracted of three samples from leaves Arbutus pavarii (Sample1= plant intact naturally grow, sample $2=$ plant growth almost normal, sample $3=$ No plant grows naturally) and $\%$ variation from the corresponding control( qurecetin as standard).

\begin{tabular}{|c|c|c|c|c|c|c|c|}
\hline \multirow{2}{*}{$\begin{array}{c}\text { concentration } \\
\text { " } \mu \mathrm{g} / \mathrm{ml} "\end{array}$} & \multicolumn{7}{|c|}{ Mean phenolic content (Standard Deviation) } \\
\hline & qurecetin & Sample1 & $\begin{array}{l}\% \\
\text { var. }\end{array}$ & Sample2 & $\begin{array}{l}\% \\
\text { var. }\end{array}$ & Sample3 & $\begin{array}{l}\% \\
\text { var. }\end{array}$ \\
\hline 100 & $\begin{array}{c}0.279( \\
0.092)\end{array}$ & $0.297(0.032) \dagger$ & $6.45 \uparrow$ & $0.276(0.002) \dagger$ & $1.07 \downarrow$ & $\begin{array}{l}0.0845( \\
0.055)^{* *}\end{array}$ & $69.7 \downarrow$ \\
\hline 200 & $0.560(0.035)$ & $0.497(0.011) \dagger$ & $11.25 \downarrow$ & $0.375(0.001)^{*}$ & $33.0 \downarrow$ & $\begin{array}{c}0.095 \\
(0.045)^{* *}\end{array}$ & $83.0 \downarrow$ \\
\hline 300 & $\begin{array}{c}0.834( \\
0.003) \\
\end{array}$ & $\begin{array}{c}0.664( \\
0.002) \dagger \\
\end{array}$ & $20.4 \downarrow$ & $0.609(0.008) \dagger$ & $27.0 \downarrow$ & $\begin{array}{c}0.141 \\
(0.075)^{* *}\end{array}$ & $83.1 \downarrow$ \\
\hline 400 & $\begin{array}{l}1.066( \\
0.009) \\
\end{array}$ & $\begin{array}{c}0.820( \\
0.090) \dagger \\
\end{array}$ & $18 \downarrow$ & $0.869(0.003) \dagger$ & $18.4 \downarrow$ & $\begin{array}{c}0.423 \\
(0.071)^{* *}\end{array}$ & $60.3 \downarrow$ \\
\hline 500 & $\begin{array}{r}1.300( \\
0.006) \\
\end{array}$ & $\begin{array}{l}1.690( \\
0.011)^{*}\end{array}$ & $30 \uparrow$ & $1.340(0.001) \dagger$ & $3.08 \uparrow$ & $\begin{array}{c}0.866 \\
(0.085)^{*} \\
\end{array}$ & $33.4 \downarrow$ \\
\hline
\end{tabular}

$\dagger$ Insignificant difference from the corresponding control at $\mathrm{P}>0.1$

* Significant difference from the corresponding control at $\mathrm{P}<0.05$

** Highly sig. difference from the corresponding control at $\mathrm{P}<0.01$

*** Very highly sig. difference from the corresponding control at $\mathrm{P}<0.001$

$\downarrow$ Decrease

$\uparrow$ Increase

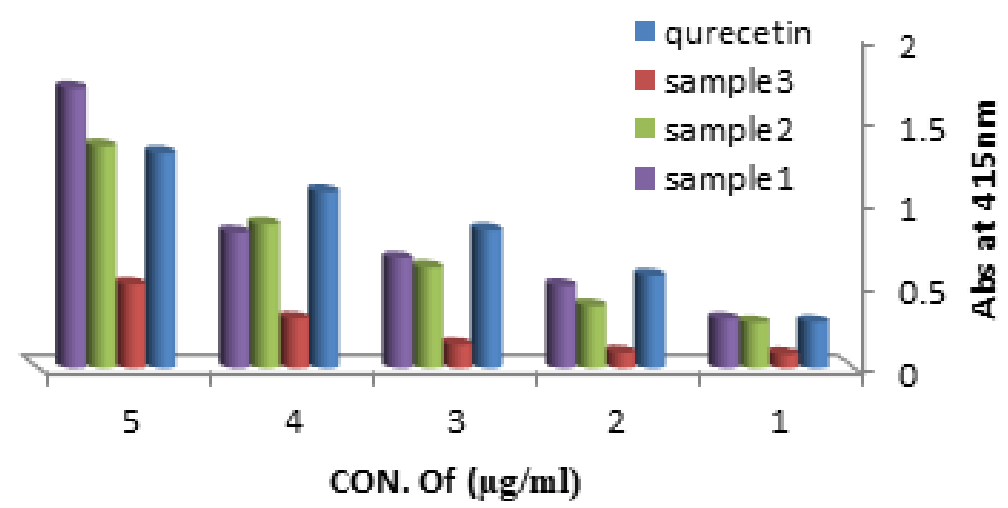

Fig10. Total flavonoids content of essential oils extracted from leaves Arbutus pavarii and qurecetin as flavonoid compound.

Table6. Reducing power assay essential oils extracted of three samples from leaves Arbutus pavarii (Sample1= plant intact naturally grow, sample $2=$ plant growth almost normal, sample $3=$ No plant grows naturally) and $\%$ variation from the corresponding control(vitamin $C$ )

\begin{tabular}{|c|c|c|c|c|c|c|c|}
\hline \multirow[b]{2}{*}{$\begin{array}{l}\text { concentration } \\
\qquad \mu \mathrm{g} / \mathrm{ml} "\end{array}$} & \multicolumn{7}{|c|}{ Mean phenolic content (Standard Deviation) } \\
\hline & vitamin $\mathbf{C}$ & Sample1 & $\begin{array}{c}\% \\
\text { var. }\end{array}$ & Sample2 & $\begin{array}{c}\% \\
\text { var. }\end{array}$ & Sample3 & $\begin{array}{c}\% \\
\text { var. }\end{array}$ \\
\hline 100 & $\begin{array}{l}0.201( \\
0.0280)\end{array}$ & $\begin{array}{c}0.503 \\
\left(0.0448^{* * * * *}\right.\end{array}$ & $150.3 \uparrow$ & $\begin{array}{l}0.564 \\
(0.07)^{* * * *}\end{array}$ & $180.6 \uparrow$ & $\begin{array}{c}0.044 \\
(0.006)^{* *}\end{array}$ & $78.1 \downarrow$ \\
\hline 200 & $\begin{array}{l}0.495( \\
0.0350)\end{array}$ & $0.875(0.0965)^{* *}$ & $76.8 \uparrow$ & $\begin{array}{l}0.871 \\
(0.0)^{* *}\end{array}$ & $75.9 \uparrow$ & $\begin{array}{c}0.104 \\
(0.002)^{* * *}\end{array}$ & $79 \downarrow$ \\
\hline 300 & $\begin{array}{l}0.697( \\
0.0087)\end{array}$ & $\begin{array}{c}1.293 \\
(0.0471)^{* * *}\end{array}$ & $85.5 \uparrow$ & $\begin{array}{c}1.321 \\
0.003)^{* *}\end{array}$ & $89.5 \uparrow$ & $\begin{array}{c}0.432 \\
(0.005)^{*}\end{array}$ & $38.0 \downarrow$ \\
\hline 400 & $\begin{array}{c}0.992( \\
0.0727) \\
\end{array}$ & $1.563(0.0266)^{*}$ & $57.6 \uparrow$ & $\begin{array}{c}1.899 \\
(0.01)^{* * *} \\
\end{array}$ & $91.4 \uparrow$ & $\begin{array}{c}0.902 \\
(0.016) \dagger \\
\end{array}$ & $9.07 \downarrow$ \\
\hline 500 & $\begin{array}{l}1.201( \\
0.0305)\end{array}$ & $\begin{array}{l}2.339 \\
(0.0401)^{* * *}\end{array}$ & $94.8 \uparrow$ & $\begin{array}{c}2.486 \\
(0.01)^{* * * *}\end{array}$ & $107.0 \uparrow$ & $\begin{array}{c}1.052 \\
(2.965) \dagger\end{array}$ & $12.41 \downarrow$ \\
\hline
\end{tabular}

$\uparrow$ Insignificant difference from the corresponding control at $\mathrm{P}>0.1$

* Significant difference from the corresponding control at $\mathrm{P}<0.05$

** Highly sig. difference from the corresponding control at $\mathrm{P}<0.01$

*** Very highly sig. difference from the corresponding control at $\mathrm{P}<0.001$

$\downarrow$ Decrease

$\uparrow$ Increase

International Journal of Advanced Research in Botany (IJARB) 


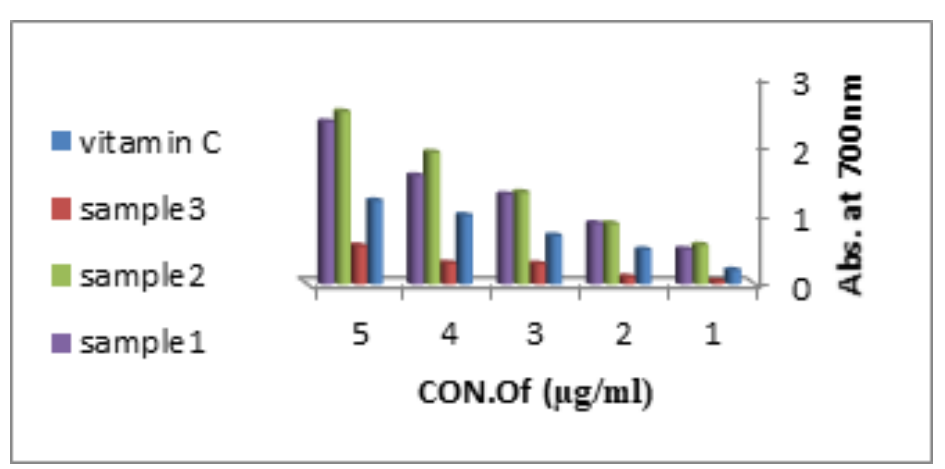

Fig11. Reducing power assay of methanol, ethanol and acetone extracted from leaves Arbutus pavarii and vitamin $C$.

Table7. DPPH radical scavenging activity of vitamin $C$, and essential oils extracted of three samples from leaves Arbutus pavarii according to \% inhibition.

\begin{tabular}{|c|c|c|c|c|c|c|c|}
\hline \multirow{2}{*}{$\begin{array}{c}\text { concentration } \\
" \mu \mathrm{g} / \mathrm{ml} "\end{array}$} & \multicolumn{7}{|c|}{ Percent of inhibition (\%) } \\
\hline & vitamin $\mathrm{C}$ & Sample1 & $\begin{array}{c}\% \\
\text { var. }\end{array}$ & Sample2 & $\begin{array}{c}\% \\
\text { var. }\end{array}$ & Sample3 & \% var. \\
\hline 100 & $92.3 \%$ & $57 \%^{*}$ & $38.2 \downarrow$ & $39 \% *$ & $57.7 \downarrow$ & $11 \%{ }^{* *}$ & $88.1 \downarrow$ \\
\hline 200 & $93.8 \%$ & $79 \%+$ & $15.8 \downarrow$ & $59 \% *$ & $37.1 \downarrow$ & $19 \%^{* *}$ & $79.7 \downarrow$ \\
\hline 300 & $95.1 \%$ & $85 \% \dagger$ & $10.6 \downarrow$ & $75 \% \dagger$ & $21.1 \downarrow$ & $27 \%^{* *}$ & $71.6 \downarrow$ \\
\hline 400 & $95.8 \%$ & $89 \% \dagger$ & $7.1 \downarrow$ & $87 \%+$ & $9.19 \downarrow$ & $33 \%{ }^{* *}$ & $65.6 \downarrow$ \\
\hline 500 & $96.7 \%$ & $97 \% \dagger$ & $0.31 \uparrow$ & $90 \% \dagger$ & $6.93 \downarrow$ & $38 \%{ }^{* *}$ & $60.7 \downarrow$ \\
\hline
\end{tabular}

$\uparrow$ Insignificant difference from the corresponding control at $\mathrm{P}>0.1$

* Significant difference from the corresponding control at $\mathrm{P}<0.05$

** Highly sig. difference from the corresponding control at $\mathrm{P}<0.01$

*** Very highly sig. difference from the corresponding control at $\mathrm{P}<0.001$

$\downarrow$ Decrease

$\uparrow$ Increase

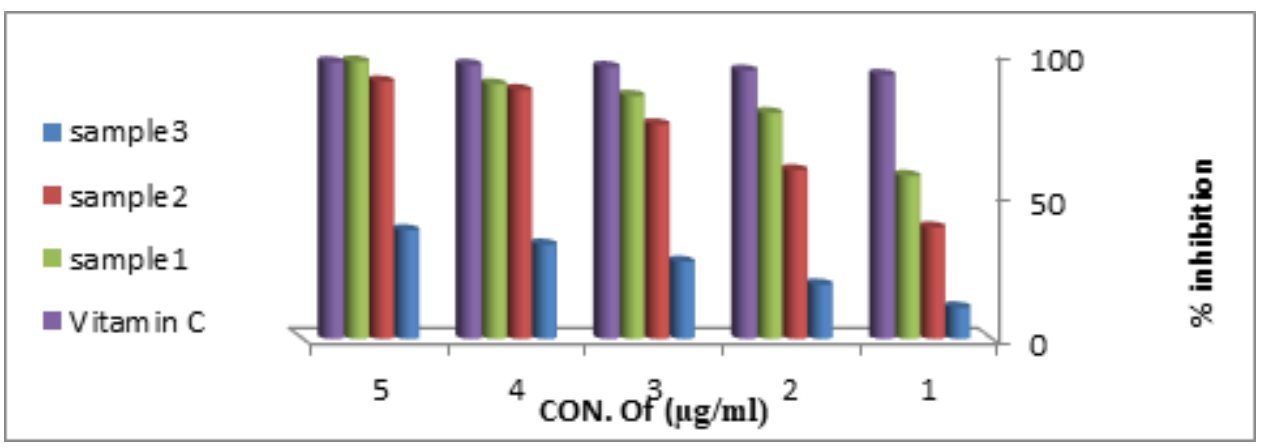

Fig12. DPPH radical scavenging activity of vitamin $C$ and essential oils extracted from leaves Arbutus pavarii according to \% inhibition.

\subsection{The GC-MS Analysis of the Essential Oils Extracted from Leaves Arbutus Pavarii:}

The retention time of the different compounds in the essential oils of Arbutus pavarii are presented in Table 8 . Thirty-four volatile compounds, representing $88.29 \%$ of the total oil composition in sample 1 , were identified in the leaves oils (Table 8). Monoterpene hydrocarbons were found to be the major group of compounds. The most abundant component found in the leaf oil was $\alpha$ pinene $(20.85 \%)$ followed by Germacrene D (16.49\%), while $\alpha$ pinene and Germacrene D in sample 2 and sample 3 were $(12.45 \%, 3.09 \%)$ and $(9.19 \%, 1.054 \%)$ respectively. Surprisingly, there were decrease of these compounds in the sample diseased (table 8).

Table8. The main components of essential oils of Arbutus pavarii L. leaves collected from Al-Jabal Al Akhdar area (A sulnta)

\begin{tabular}{|l|c|c|c|c|}
\hline \multirow{2}{*}{ Constituents } & \multicolumn{3}{|c|}{ Area \% } & \multirow{2}{*}{$*$ Rt (min) } \\
\cline { 2 - 4 } & sample 1 & Sample 2 & Sample 3 & \\
\hline$\alpha$-pinene & 20.85 & 12.45 & 3.09 & 4.16 \\
\hline
\end{tabular}


The Importance of using Arbutus Pavarii Plant as a Medicinal Herbal Plant and its Benefits in our Daily Life

\begin{tabular}{|c|c|c|c|c|}
\hline$\beta$-myrcene & 1.36 & 0.23 & - & 5.06 \\
\hline Terpinolene & 0.07 & - & - & 5.26 \\
\hline$\beta$-phellandrene & 3.84 & 1.79 & 0.02 & 5.91 \\
\hline Trans-Caryophyllene & 5.44 & 5.00 & 2.087 & 14.66 \\
\hline $\begin{array}{l}4,7,10- \\
\text { Cycloundecatriene, } 1,1,4,8 \\
\text { tetramethyl-,cis,cis,cis }\end{array}$ & 5.31 & 4.13 & 0.12 & 15.37 \\
\hline Germacrene D & 16.49 & 9.19 & 1.054 & 16.05 \\
\hline Germacrene B & 2.73 & 1.72 & - & 17.46 \\
\hline$\alpha-$ cedrol & 0.36 & - & - & 18.27 \\
\hline +. alpha.-longipinene & 2.98 & 2.082 & 0.471 & 18.08 \\
\hline $\begin{array}{l}\text { Naphthalene,1,2,3,4,4a,5,6,8a,- } \\
\text { octahydro-7-methl-4- } \\
\text { methylene-1- (1-methylethyl)- } \\
\text { (1.alpha,4a.alpha.,8a.alpha) }\end{array}$ & 5.22 & 2.011 & 0.57 & 16.23 \\
\hline Camphene & 0.29 & - & - & 4.32 \\
\hline$\beta$-pinene & 0.49 & - & - & 4.81 \\
\hline 1-phellandrene & 0.39 & - & - & 5.33 \\
\hline delta.3-carene & 0.40 & - & - & 5.46 \\
\hline$\alpha-$ terpinolen & 0.23 & - & - & 7.10 \\
\hline Terpinolene & 5.13 & 5.13 & 2.093 & 13.11 \\
\hline Linalool & 0.47 & - & - & 7.37 \\
\hline Citronellol & 0.63 & - & - & 10.30 \\
\hline$\alpha$-cubebene & 0.39 & - & - & 13.60 \\
\hline$\beta$-bourbonene & 0.22 & - & - & 13.80 \\
\hline$\beta$-elemene & 0.93 & - & - & 13.94 \\
\hline Widdrene & 1.24 & 0.53 & - & 14.83 \\
\hline$\alpha$-gurjunene & 0.35 & - & - & 16.40 \\
\hline Zingiberene & 0.43 & - & - & 16.92 \\
\hline delta.-cadinene & 5.63 & 5.00 & 3.73 & 16.81 \\
\hline$\alpha$-muurolene & 0.43 & - & - & 17.01 \\
\hline$\alpha$-calacorene & 0.24 & - & - & 17.10 \\
\hline Elemol & 0.61 & - & - & 17.28 \\
\hline caryophyllene oxide & 2.06 & 1.890 & 0.281 & 17.95 \\
\hline Fonenol & 0.36 & - & - & 18.58 \\
\hline$\alpha$-ylangene & 1.33 & 0.072 & - & 19.03 \\
\hline$\beta$ - selinene & 0.30 & 0.30 & 0.30 & 19.54 \\
\hline vulgarol B & 1.09 & 0.873 & - & 19.88 \\
\hline
\end{tabular}

*Rt: Retention time obtained by chromatogram.

Sample1= plant intact naturally grow, sample2= plant growth almost normal and sample $3=$ No plant grows naturally.

The Results of Morphological and Growth Characteristics are Given in Table (9). From this Table, the Sample Number (1) Reflected the Highest Mean Value of Plant Height and Stem Diameter. They were 222.67 Cm and 16.42 Cm, Respectively.

Table9. Growth in term of plant height $(\mathrm{cm})$, stem diameter $(\mathrm{cm})$ and leaf dry weight $(\mathrm{mg})$ of Arbutus pavarii . in ELGabal EL-Ahkdar area.

\begin{tabular}{|l|c|c|c|c|c|c|}
\hline \multicolumn{1}{|c|}{ Sample Name } & \multicolumn{2}{|c|}{$\begin{array}{c}\text { Plant height } \\
\text { (cm) }\end{array}$} & \multicolumn{2}{c|}{ Stem diameter (cm) } & \multicolumn{2}{c|}{$\begin{array}{c}\text { Leaf dry weight } \\
\text { (mg) }\end{array}$} \\
\hline & Mean & (SD) & Mean & \multicolumn{1}{c|}{ (SD) } & \multicolumn{1}{c|}{ Mean } & (SD) \\
\hline Healthy sample & 222.67 & $(21.35)$ & 16.42 & $(5.90)$ & 3.0234 & $(0.19)$ \\
\hline Semi healthy sample & 216.55 & $(17.93)$ & 11.22 & $(3.14)$ & 3.2058 & $(0.23)$ \\
\hline Sample sick & 214.23 & $(23.47)$ & 9.89 & $(2.05)$ & 3.8240 & $(0.11)$ \\
\hline
\end{tabular}


The Results Obtained in this Study as Shown in Table(10) Indicate that the Healthy Sample Contain High Amount of Chlorophyll A, Chlorophyll B and Carotenoids as Compared with the Semi Healthy Sample and Sample Disease.

Table10. Estimation of photosynthetic pigments of Arbutus pavarii. leaves in EL-Gabal EL-Ahkdar area.

\begin{tabular}{|c|c|c|c|}
\hline Sample & $\begin{array}{c}\text { Chlorophyll A } \\
(\mathbf{~ m g / m l})\end{array}$ & $\begin{array}{c}\text { Chlorophyll B } \\
(\mathbf{~ m g / m l})\end{array}$ & $\begin{array}{c}\text { Carotenoids } \\
(\mathbf{~ m g / m l})\end{array}$ \\
\hline Healthy sample & 5.7708 & 4.894 & 6.323 \\
\hline Semi healthy sample & 5.670 & 4.721 & 5.126 \\
\hline Sample sick & 4.346 & 2.915 & 3.503 \\
\hline
\end{tabular}

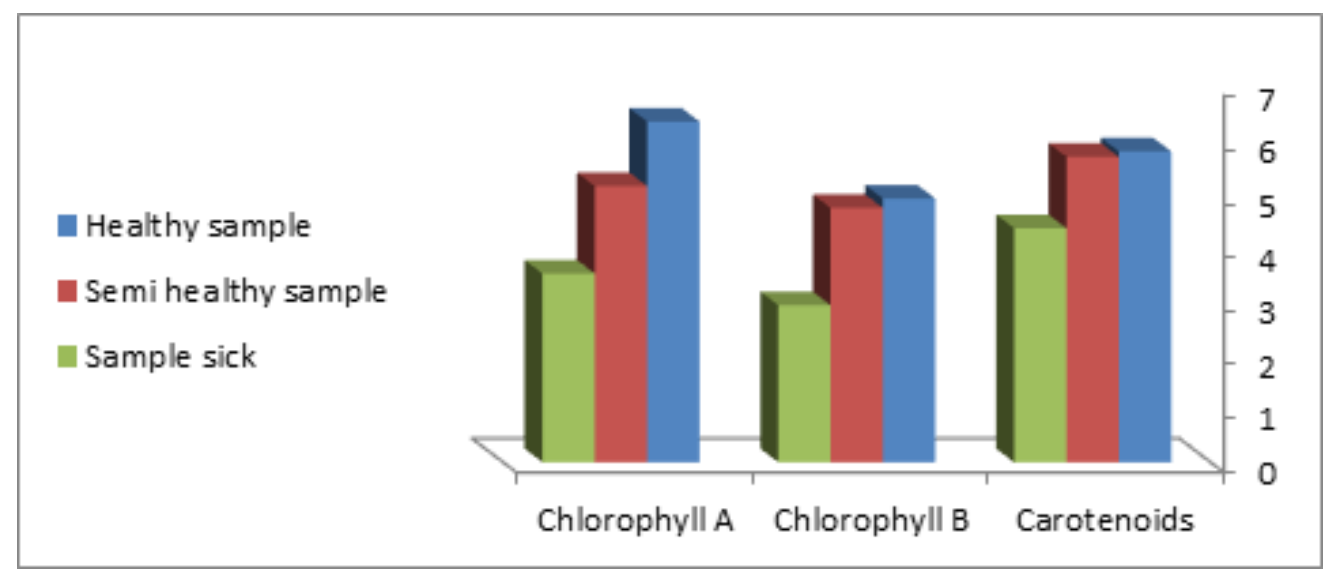

Fig13. Estimation of photosynthetic pigments of Arbutus pavarii. leaves in EL-Gabal EL-Ahkdar area

As shown in Fig (14) decreased the number of bacteria in the sub- branches of Semi- healthy sample but increased the number of bacteria in diseased sample. The number of bacteria in the sample healthy at the main branch of the highest less than the bottom, but in the semi-healthy sample, the number of bacteria from the top down and more of them there are more in the center, while in diseased sample, the number of bacteria is too much and this shown in Fig (15).

In addition, the number of bacteria in lichens the number of bacteria in three samples and an equal number was more than 300 , as shown in the Fig (16).

Through our results was observed that the number of bacteria in the green leaves of the sample healthy sample more than semi-healthy sample, as shown in Fig (17), while the number of bacteria in the brown leaves in all samples were large Fig (18).

Fig (19) indicated that the number of bacteria taken of selected locations of Arbutus pavarii tree in an environment actinomycetes were a few specific sites, but the number of bacteria is high in lichens and green leaves and soil.

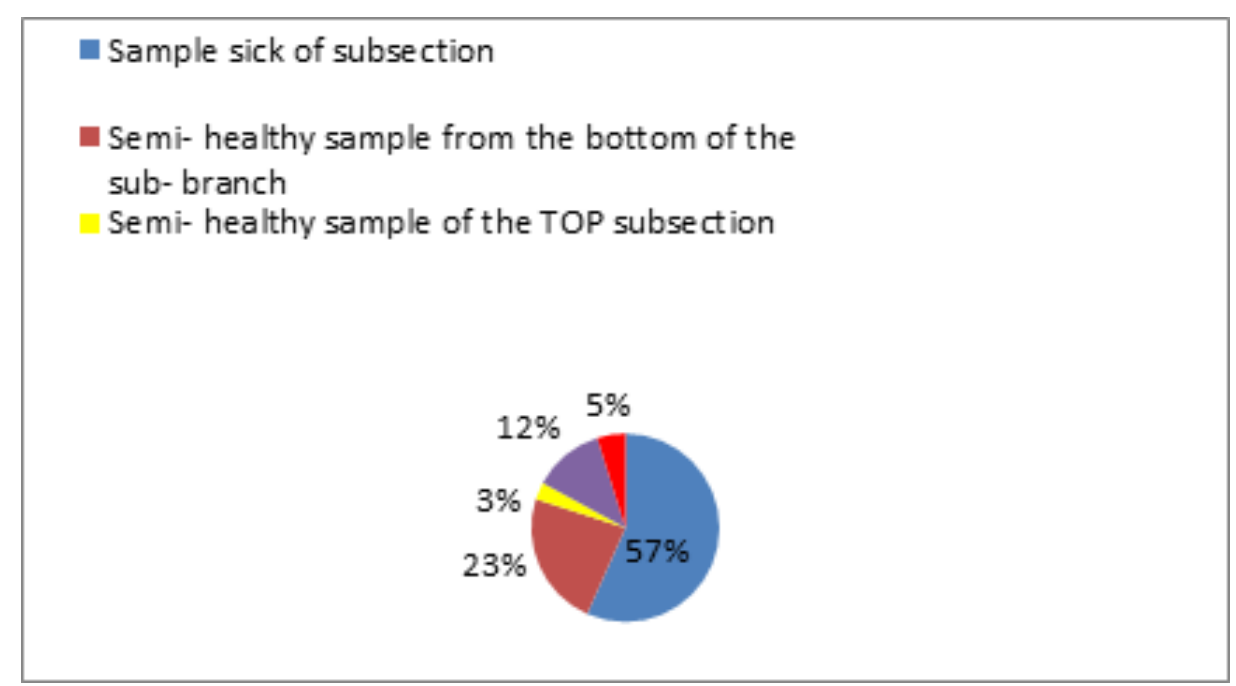

Fig14. The number of bacteria on the sub-branches in Arbutus pavarii. 
The Importance of using Arbutus Pavarii Plant as a Medicinal Herbal Plant and its Benefits in our Daily Life

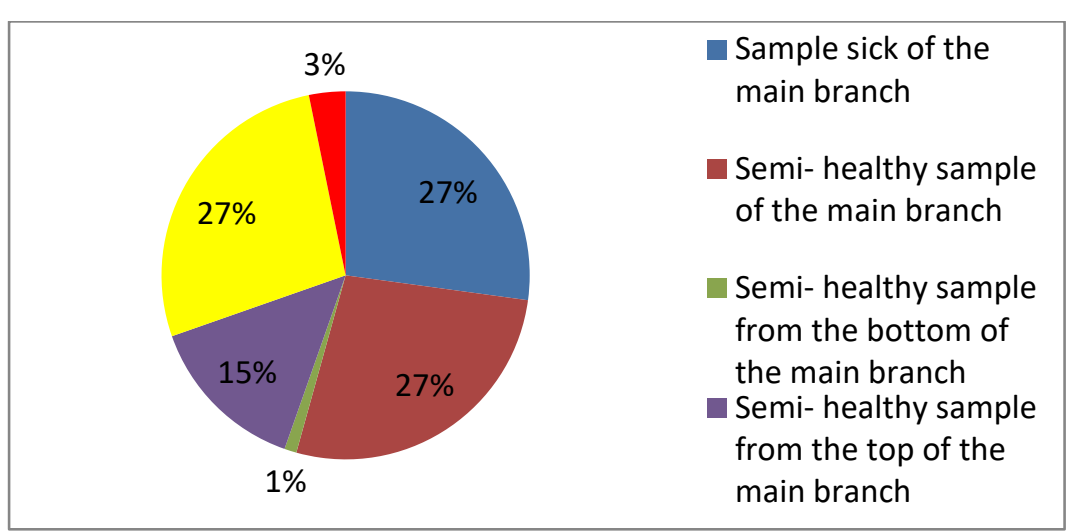

Figure15. The number of bacteria on the main branch in Arbutus pavarii.

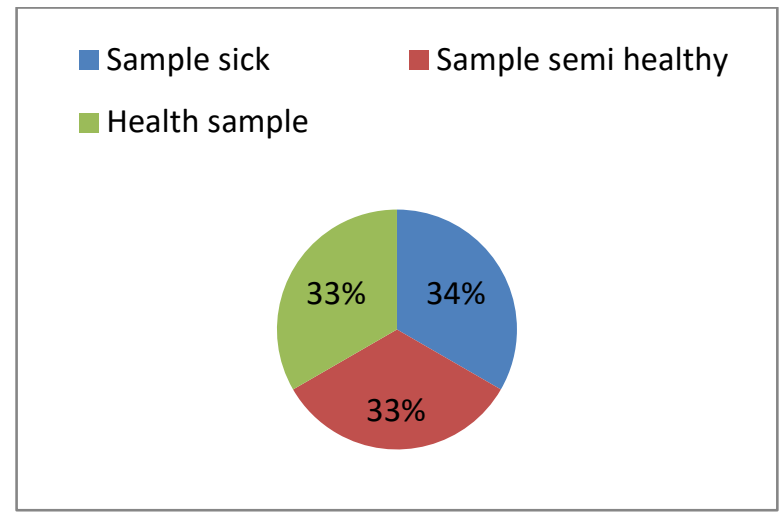

Figure16. The number of bacteria on lichens in Arbutus pavarii plant.

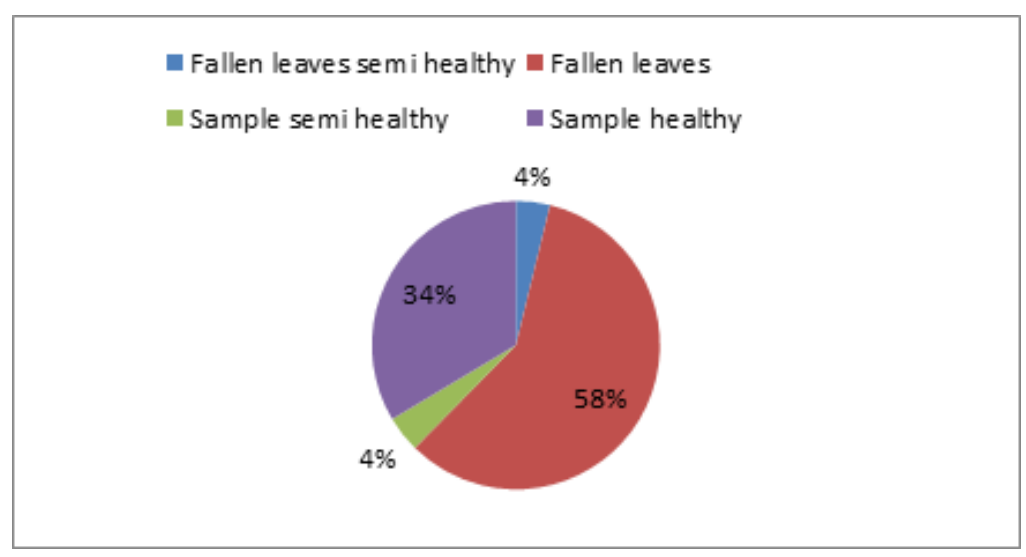

Figure17. The number of bacteria on green leaves in Arbutus pavarii plant.

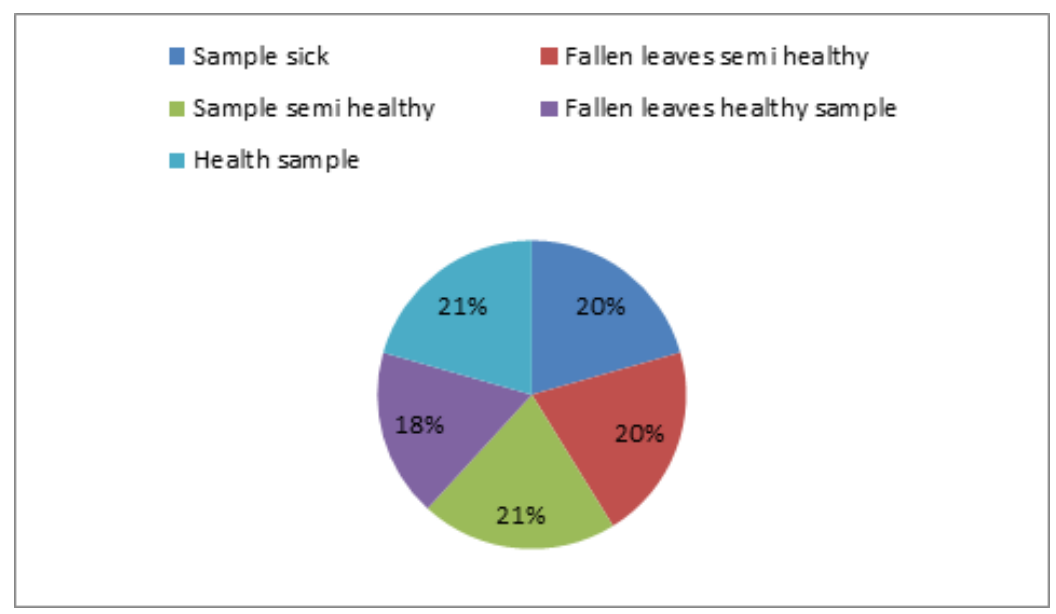

Fig18. The number of bacteria on brown leaves in Arbutus pavarii plant. 
The Importance of using Arbutus Pavarii Plant as a Medicinal Herbal Plant and its Benefits in our Daily Life

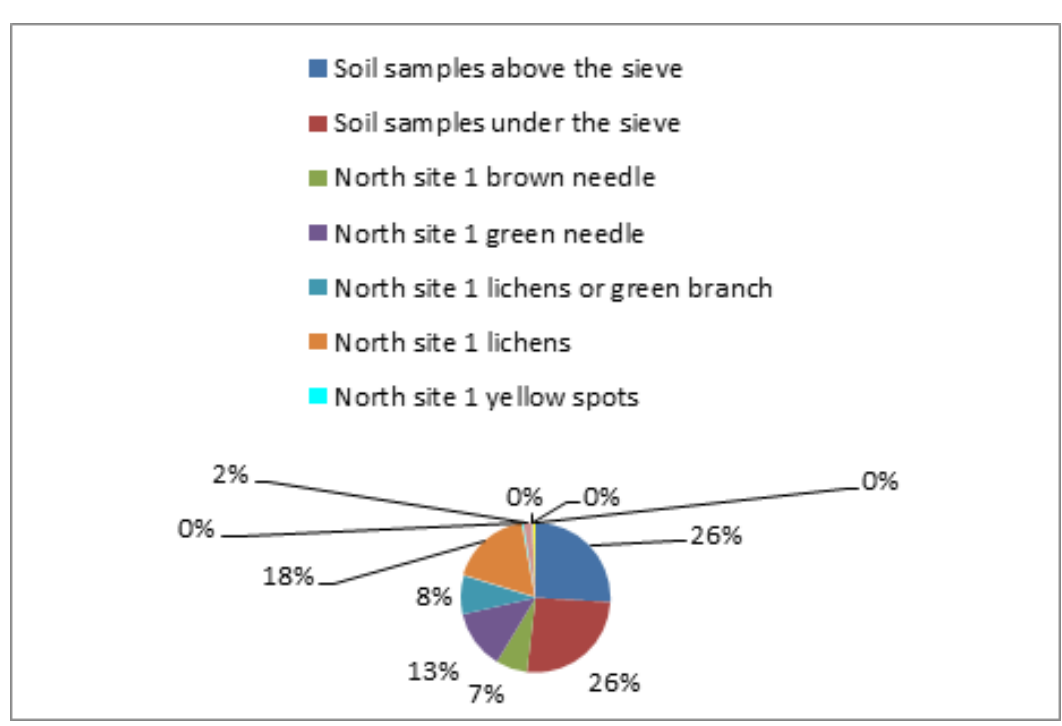

Figure19. The number of bacteria and total Actinomycetes mass

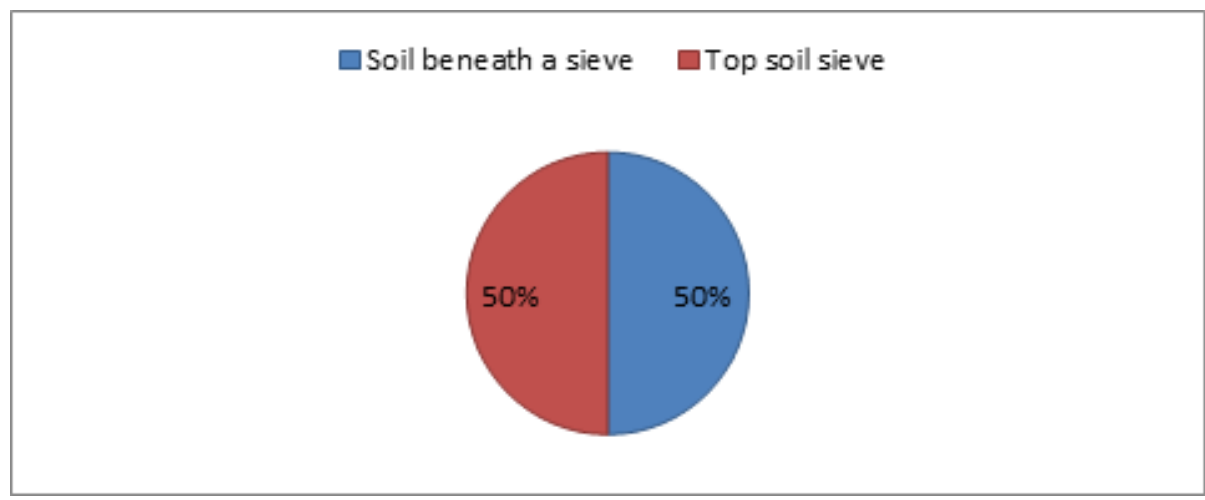

Figure20. The number of bacterial colonies in soil samples

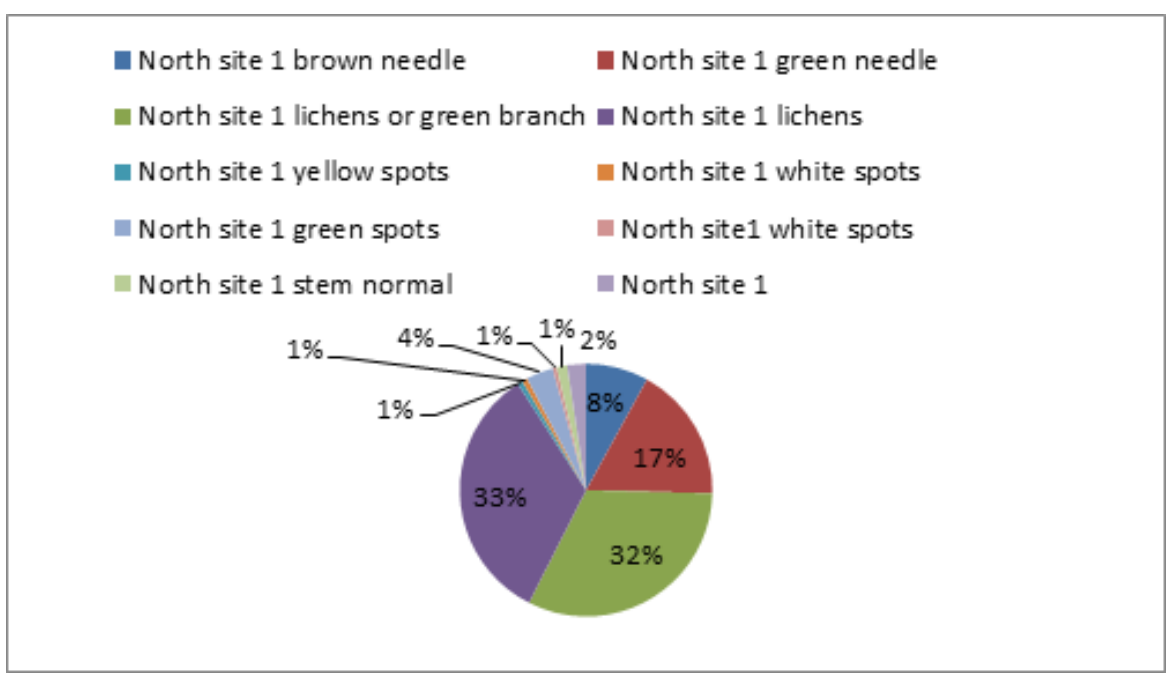

Figure21. The number of bacteria in the Nutrient Agar media taken by Wipes.

\section{REFERENCES}

[1] Alarcao-E-Silva M., Leitão A., Azinheira H. and Leitão M. (2001). "The Arbutus Berry: Studies on its color and chemical characteristics at two mature stages." Journal of Food Composition and Analysis 14(1): 27-35.

[2] Amić D., Davidović-Amić D., Bešlo D. and Trinajstić N. (2003). "Structure-radical scavenging activity relationships of flavonoids." Croatica chemica acta 76(1): 55-61.

[3] Ayaz F., Kucukislamoglu M. and Reunanen M. (2000). "Sugar, non-volatile and phenolic acids composition of strawberry tree (Arbutus unedo L. var. ellipsoidea) fruits." Journal of Food Composition and Analysis 13(2): 171-177. 
[4] Barros L., Carvalho A. M., Morais J. S. and Ferreira I. C. (2010). "Strawberry-tree, blackthorn and rose fruits: Detailed characterisation in nutrients and phytochemicals with antioxidant properties." Food chemistry 120(1): 247-254

[5] El abidi N. and S. El shatshat (2017) Qualitative Criteria of The endemic Arbutus pavarii Pamp. Libyan Honey, EPRA International Journal of Research and Development, 1(2): 132-135.

[6] El shatshat S., (2009) Biological conservation of the endemic Arbutus pavarii Pamp.: Seed germination as attempt, International journal of Human geography and Environmental Studies, 1: 20-22.

[7] El shatshat S., G.,Thabt, and N. Elhashani (2009) Critical situation of the vegetation of EL- Gabal EL-Akhdar area: Physical and anthropogenic factors and their effects on wild utilized and endemic taxa, International Journal of Sustainability Science and Studies, 1: 60-63

[8] El shatshat S. and O, Al silini (2017) Foraging Apis mellifera L. honey bees on three wild Forage plant resources in El-Gabal El-akhdar area, Libya. International Journal of Multidispilinary Research, 3, 8, 39-43.

[9] Fortalezas S., Tavares L., Pimpão R., Tyagi M., Pontes V ,.Alves P. M., McDougall G., Stewart D., Ferreira R. B. and Santos C. N. (2010). "Antioxidant properties and neuroprotective capacity of strawberry tree fruit (Arbutus unedo)." Nutrients 2(2): 214-229.

[10] Guimarães R., Barros L., Dueñas M ,.Carvalho A. M., Queiroz M. J. R., Santos-Buelga C. and Ferreira I. C. (2013). "Characterisation of phenolic compounds in wild fruits from Northeastern Portugal." Food chemistry 141(4): 3721-3730.

[11] Hamad H., H, Ibrahim H., H, Mariam H., G and Mojahidul I" .)3122( .Comparative phytochemical and antimicrobial investigation of some plants growing in Al Jabal Al-Akhdar." JJ Nat Prod Plant Resour 1: 1523.

[12] Hussain I., Khan L., Khan M., Khan F. and Ayaz S. (2010). "UV spectrophotometric analysis profile of ascorbic acid in medicinal plants of Pakistan." World Applied Sciences Journal 9(7): 800-803.

[13] Isbilir S. S., Orak H. H., Yagar H. and Ekinci N. (2012). "Determination of antioxidant activities of strawberry tree (Arbutus unedo L.) flowers and fruits at different ripening stages." Acta Sci. Pol 11: 223-237.

[14] Markovski, A. (2017) Morphological characteristics of greek strawberry tree (arbutus andrachne 1.) genotypes, Acta Agricultura Serbica, 44, 193-206.

[15] Mendes L., de Freitas V., Baptista P. and Carvalho M. (2011). "Comparative antihemolytic and radical scavenging activities of strawberry tree (Arbutus unedo L.) leaf and fruit." Food and chemical toxicology 49(9): 2285-2291.

[16] Molina, M., De-santayana, M., Aceituno, L., Morales, R. and J. Tardio (2011) Fruit production of strawberry tree (Arbutus unedo L.) in two Spanish forests, Forestry, 84, 4, 419-429.

[17] Nagata M. and Yamashita I. (1992). "Simple method for simultaneous determination of chlorophyll and carotenoids in tomato fruit." Journal-Japanese Society of Food Science and Technology 39: 925-925.

[18] Nasar M. A., Jarrari A., Naseer M. A., Subhani T. F., Shetty B. V. and Shakeel F. (2009). "Antioxidant status of atorvastatin in hypercholesterolemic patients." Journal of the Serbian Chemical Society 74(10): 1063-1073.

[19] Oliveira I., Baptista P., Malheiro R., Casal S., Bento A. and Pereira J. A. (2011). "Influence of strawberry tree (Arbutus unedo L.) fruit ripening stage on chemical composition and antioxidant activity." Food Research International 44(5): 1401-1407.

[20]Pawlowska A. M., De Leo M. and Braca A. (2006). "Phenolics of Arbutus unedo L.(Ericaceae) fruits: identification of anthocyanins and gallic acid derivatives." Journal of agricultural and food chemistry 54(26): 10234-10238.

[21]Phang C.-W., Malek S. N. A., Ibrahim H. and Wahab N. A. (2011" .)Antioxidant properties of crude and fractionated extracts of Alpinia mutica rhizomes and their total phenolic content." African journal of pharmacy and pharmacology 5(7): 842-852.

[22] Sweetman S. C. (2002). "Martindale: The Complete Drug Reference Pharmaceutical Press." London (UK) 33.

[23] Tobias A. L. (1995). "CALutzKPrzytulski Nutrition and Diet Therapy1994 From FA Davis Company/Publishers1915 Arch Street, Philadelphia, PA 191030-8036-5681-5750 pp, softcover, \$29.95." Journal of Nutrition Education 27(1): 47-48.

[24] Al-Rehaily, A.J., Alqasoumi, S.I., Yusufoglu, H.S., Al-Yahya, M.A., Demirci. B., Tabanca, N., Wedge D.E., Demirci, F., Bernier, U.R., Becnel, J., Temel, H.E., Baser. K.H. 2014. Chemical Composition and Biological Activity ofHaplophyllum tuberculatum Juss. Essential Oil. Journal of Essential Oil Bearing Plants. 17 (3): 452-459.

[25] Bertsouklis, K.F., and M, Papafotiou. 2009. In vitro propagation of Arbutus andrachne L. Acta Hort. 813:477479. 
[26]El-Darier, S.M., and F.M, El-Mogaspi. 2009. Ethnobotany and Relative Importance of Some Endemic Plant Species at El-Jabal El-Akhdar Region (Libya). World Journal of Agricultural Sciences 5 (3): 353-360.

[27]Elmaghrabi, A.M., and S.J, Ochatt. 2006. Isoenzymes and flow cytometry for the assessment of true-totypeness of calluses and cell suspension of barrel medic prior to regeneration. Plant Cell Tissue Org Cult 85:31-43.

[28]Elmaghrabi, A.M., Abughnia, E., Hamoud, S. 2017. In vitro propagation of the wild medicinal plant, caper (Capparis spinosa L.). African Journal of Biotechnology. ISSN: 1684-5315. http://www.academicjournals.org/AJB.

[29]El-Naggar, E.B., El-Darier, S.M., El-Mekanen, A.A., Švajdlenka, E., Zemlièka, M. 2014. Chemical Composition of Essential Oil of Haplophyllum tuberculatum (Rutaceae) Grow Wild in Different Habitats of Egypt. Global Journal of Pharmacology 8 (3): 385-393.

[30] George, E.F., Hall, M.A., De Klerk, G.-J. 2008. Plant Propagation by tissue culture, 3rd Edition. Springer.

[31] Gonçalves, J.C., Diogo, G., Amâncio, S. 1998. In vitro propagation of chestnut (Castanea sativa $\times$ C. crenata): Effects of rooting treatments on plant survival, peroxidase activity and anatomical changes during adventitious root formation. Sci. Hort. 72(3): 265-275.

[32] Gholami, M., Javidnia, K., Miri, R., Soltani, M. 2009. Micropropagated Haplophyllum patavinum HandMazz. (Rutaceae) Oil as rich source of $\alpha$-Palmitolactone. Iranian Congress of Physiology and Pharmacology. (19). http://en.seminars.sid.ir/ViewPaper.aspx?ID=1607

[33]Louhaichi, M., Salkini, A.K., Estita., H.E., Belkhir, S. 2011. Initial Assessment of Medicinal Plants Across the Libyan Mediterranean Coast. Advances in Environmental Biology, 5(2): 359-370.

[34] Murashige, T., and F, Skoog. 1962. A revised medium for rapid growth and bioassays with tobacco tissue cultures. Physiol. Plant. 15:473-497.

[35] Puricelli, L., Innocenti, G., Dellemonache, G., Caniato, R., Filippini, R., Cappelletti, E.M. 2002 In vivo and in vitro production of alkaloids by Haplophyllum patavinum. Natural Product Letters, Vol. 16, No. 2, pp. 95100.

[36] Torres, J.A., Valle, F., Pinto, C., Garcia-Fuentes, A., Salazar, C., Cano, E. 2002. Arbutus unedo L. communities in southern Iberian Peninsula mountains. Plant Ecol. 160:207-223.

[37] Abidi, E., J. Habib, T. Mahjoub, F. Belhadj, M. Garra, and A. Elkak. 2016. Chemical composition, antioxidant and antibacterial activities of extracts obtained from the roots bark of Arbutus andrachne L. a Lebanese tree. International Journal of Phytomedicine 8:104-112. [Google Scholar]

[38] Abidi, E., J. Habib, A. Yassine, N. Chahine, T. Mahjoub, and A. Elkak. 2016. Effects of methanol extracts from roots, leaves, and fruits of the Lebanese strawberry tree (Arbutus andrachne) on cardiac function together with their antioxidant activity. Pharmaceutical Biology 54 (6):1035-1041. doi: 10.3109/13880209.2015.1100638. [Taylor \& Francis Online], [Web of Science ®], [Google Scholar]

[39]Abu-Dahab, R., and F. Afifi. 2007. Antiproliferative activity of selected medicinal plants of Jordan against a breast adenocarcinoma cell line (MCF7). Scientia Pharmaceutica 75 (3):121-136. doi: 10.3797/scipharm.2007.75.121. [Crossref], [Google Scholar]

Citation: Halima Omar Jadallah, et.al (2020). "The Importance of using Arbutus Pavarii Plant as a Medicinal Herbal Plant and its Benefits in our Daily Life". International Journal of Advanced Research in Botany (IJARB), 6(2), pp.1-14. DOI: https://doi.org/10.20431/2455-4316.0602001

Copyright: () 2020 Authors, This is an open-access article distributed under the terms of the Creative Commons Attribution License, which permits unrestricted use, distribution, and reproduction in any medium, provided the original author and source are credited. 